plant from a distant part of the world, e.g. the date oases of California and Arizona, the durum wheat areas of the great plains, the rice fields of California and Texas. Prof. Kellogg remarked that the plants which grow in the colder regions of the earth are mostly species which have crept out of the tropics, adapting themselves as they have spread north and south to the conditions of colder climates, and he thinks there are probably ten times as many undiscovered useful plants remaining in the tropics as are to be found in the colder regions. The plant breeders of the United States are striving to select the hardiest of these tropical species and to adapt them for cultivation as far north as they will grow.

The conservation of migrating birds of practical and æsthetic value affords another example of useful international biology, for the extensive migrations of these birds require that conservation shall hold good in the extent of their range. The rational use and protection of the animals of the oceans that wash the coasts of North and South America was also cited, e.g. the fur seals of the Pacific were saved from extinction by international agreements made in I9II between Great Britain, Russia, Japan, and the United States. But the sperm whale is passing, and unless international action is taken it will soon be gone.

Finally, Prof. Kellogg directed attention to the international exchange of human beings - the matter of emigration and immigration with all the perplexing biological problems inherent to it. While many people consider the economic and political significance of the problem, it is incidental to and determined by the biological results. The National Research Council of the United States has a special committee at work on "the scientific problems of human migrations," for it is fully realised that the strength of the nation rests at bottom on the kind of heredity possessed by the people of the nation-it rests at bottom on biological factors.

\section{Petroleum in the Maracaibo Region, Venezuela.}

THE Maracaibo Basin, situated in western Venezuela, is an area of some 25,000 square miles, embracing the State of Zulia and parts of the States of Mérida, Táchira, and Trujillo; within this region occur the principal oilfields of Venezuela, while those of the State of Falcon, lying to the east, are geologically connected therewith. Though the presence of oil in this country was known in the early days of the Spanish occupation, commercial exploration did not commence until 1878, when the Government granted a small lease in the State of Táchira; progress was slow, however, and it was not until I9I 2 that important developments were undertaken, resulting in the discovery of the now famous Mene Grande oilfield. To-day practically the whole of the basin area is held under exploration or prospecting licences, and besides Mene Grande, the oilfields of La Rosa, Ambrosio, El Mene, La Concepcion, La Paz, Rio Palmar, Rio de Oro, and some potential petroliferous territory in the south, have been discovered.

Geologically the Maracaibo Basin corresponds with a vast geosyncline, the centre of which is occupied by Lake Maracaibo; the peripheral mountain ranges to the west, south, and east are composed of igneous and metamorphic rocks flanked by Tertiary and Cretaceous sediments, of which the Miocene formation is conspicuous for its associated gas and oil seepages. West and south of the lake the structures trend N.E.-S.W., thus conforming to the prevalent Andean trend in this part of the country; east of the lake, especially in the Bolivar district, the E.-W. influence of Caribbean tectonics is shown by the major folds. The chief characteristic of all the structures within the basin is their great linear development, usually coupled with gently dipping rocks. The best-known folds are the Mene Grande-Curaçao anticline (with its curious 'spurs' or 'lobes' running at right angles, and on which the Ambrosio and La Rosa fields are located), the Rio de Oro and La Tarra anticlines southwest of the lake, and the Rio Poco fold running parallel to the Mérida Range in the south.

The most important field is that of Ia Rosa situated 27 miles S.E. of Maracaibo city, the scene of a famous gusher in 1922 , Barroso No. 2, which flowed a million barrels of oil in nine days; since then 125 wells on this field have accounted for $12,000,000$ barrels of oil. The Mene Grande field yielded $18,000,000$ barrels up to the end of 1925, the oil being of an asphaltic nature with gravity 0.956 ; it is piped to and refined at San Lorenzo, thence shipped by lake steamer to Curacao and elsewhere. The El Mene field has produced $4,400,000$ barrels from about 50 wells and is noted for its low gravity oil $(0.850)$ and high petrol and kerosene yields ( 35 and 38 per cent. respectively). The other fields are smaller, though in most cases important extensions are anticipated. Mr. Campbell M. Hunter, from whose paper read before the Institution of Petroleum Technologists on April I3 the foregoing details are taken, is of the opinion that production for this year in the Maracaibo Basin will substantially exceed $30,000,000$ barrels, thus placing Venezuela as the fifth, if not the fourth, largest oilproducing country in the world, a remarkable rise in a little more than seven years.

\section{University and Educational Intelligence.}

CAMBridge.- - The Civil Commissioner for the Eastern Division has written to the Vice-Chancellor tendering to the University the congratulations and thanks of His Majesty's Government for the very notable part it played in assisting towards maintaining essential services during the recent critical period. About 4000 students were enrolled for national service, more than 2000 were actually called up for work, and enthusiastic appreciation has been generally expressed by those who secured from the undergraduates services "willingly given and unselfishly and efficiently performed."

Notice is given that a professor of mineralogy, in succession to the late Prof. Lewis, will be elected on June 26. Candidates are requested to communicate with the Vice-Chancellor on or before June I9.

The Council has proposed graces for the conferring of the following honorary degrees among others: LL.D. on Sir Samuel Hoare, Mr. Ramsay MacDonald, and Sir Frederick Maurice; and Sc.D. on Sir Josiah Stamp.

Sir Arthur Shipley, Master of Christ's College, is being re-appointed as representative of the University on the Council of the Marine Biological Association.

Applications are invited for the John Lucas Walker studentship in pathology, value $300 l$. a year and tenable under certain conditions for three years. Applications must be sent to reach Prof. H. R. Dean, Pathological Laboratory, Medical School, Cambridge, before June I5.

EDINBURGH.-In recognition of the work done by students of the University at Leith Docks during the recent strike, Mr. Thomas Cowan, a retired shipowner, has sent a cheque for Io,oool. for the general purposes of the University. In a letter sent with the cheque 
Mr. Cowan, who was chairman of the Emergency Committee of the Leith Dock Commissioners, states that he was greatly impressed with the enthusiasm, initiative, and working capacity of the 270 students who undertook service at the docks and helped to relieve the congestion of traffic there.

Liverpool.-The Senate and Council of the University have resolved to confer the degree of Master of Science, ex officio, on Mr. Herbert Clifton Chadwick in consideration of meritorious services rendered to the staff and students, and of distinction in Zoological research during the period 1897-I922, when he was curator of the Marine Biological Station at Port Erin, Isle of Man.

Two post-graduate research fellows will shortly be appointed to the Munitions Committee Research Fellowships, and applications are invited from graduates of the University engaged in industry or research. The value of each fellowship is $250 l$. for the first year and $350 l$. for a second if the appointment be renewed. Applications should reach the Dean of the Faculty of Engineering before June ${ }^{5}$.

Prof. A. Stock of Dahlem, Berlin, has been appointed Director of the Chemical Institute at the Technische Hochschule in Carlsruhe.

Prof. Bohuslav Brauner, director of the Chemical Institut of the Charles University of Prague and an Hon. D.Sc. of the University of Manchester, has been elected an honorary member of the American Chemical Society.

THE degree of Doctor Rerum Naturalium has been conferred in the Charles IV. University of Prague upon Mr. Edward Browning Sanigar, of Sheffield, for his thesis "The Electrolysis of Complex Cyanides with the Dropping Mercury Cathode." This is the fourth doctorate of this University conferred in recent years on an Englishman.

The Carnegie Endowment for International Peace has three divisions: Intercourse and Education, International Law, and Economics and History. A report on the work of the first division has recently been issued by the Director, Dr. Nicholas Murray Butler, who is also president of the Endowment. It tells first of the progress of the arrangements for the restoration of the library of the University of Louvain. A sum of $200,000 l$., towards which the Carnegie Endowment has contributed 31,400l., has been collected, and this will suffice not only for restoration but also for a maintenance endowment of $20,000 l$. Chief among the projects to which funds were allotted during the year is a conference of representatives of the Press of the United States which was to be held with the co-operation of the Academy of Political Science in May in the vicinity of New York. The Division has also invited some fifty American college and normal school teachers of international law and international relations in the United States to visit Paris, The Hague and Geneva during August and September next. At Geneva this party will be in charge of the American Committee of the Geneva Institute of International Relations, to which the Endowment gave 800 l. last year. The Committee maintains an office for the reception of English-speaking visitors who come to Geneva to study international co-operation. The report announces the constitution of a Comité d'Administration to serve as an executive committee of the Division for work in Europe with offices at the Centre Européen, I73 Boulevard Saint-Germain, Paris. It is about to issue a new quarterly international review, L'Esprit International.

\section{Contemporary Birthdays.}

June 5, r843. Dr. Samuel Garman.

June 6, I842. Mr. Henry Martyn Taylor, F.R.S

June 7, 1877. Prof. Charles G. Barkla, F.R.S.

June 7, 1868. Prof. John S. Townsend, F.R.S.

June 9, I875. Dr. Henry Hallett Dale, F.R.S.

June I0, r866. Lord Montagu of Beaulieu, K.C.I.E.

June II, I867. Prof. Charles Fabry.

Dr. SAMUEL GARMAN, the veteran naturalist, foreign member of the Linnean Society, was born at Indiana, U.S.A. Graduating at Illinois State Normal University, he came for a brief period under the guidance of Louis Agassiz. Dr. Garman has been on the herpetological and ichthyological staff of the Museum of Comparative Zoology, Harvard University, since r87 . He accompanied the late Alexander Agassiz on most of his South American expeditions connected with deep-sea survey work. Dr. Garman is the author of "The Reptiles of Easter Island" (I908).

Mr. H. M. TAYLOR was born at Bristol and educated at Wakefield Grammar School and Trinity College, Cambridge, graduating (I865) third wrangler. In this year the late Lord Rayleigh was the senior wrangler, and the late Prof. Alfred Marshall, the economist, second wrangler. Being blind himself, Mr. Taylor has long been personally identified with the production of embossed books on scientific subjects. We believe that he once composed a standard algebraical treatise in Braille type, afterwards read the copy with his fingers, and again, later, read the proof.

Prof. Barkla, a Lancashire man, born at Widnes, was educated at University College, Liverpool, going from there to Trinity College, Cambridge, where early he came under the inspiring influence of Sir Joseph J. Thomson. He was appointed Wheatstone professor of physics in King's College, London, in x9o9, and since I9I 3 he has occupied the chair of natural philosophy in the University of Edinburgh. Prof. Barkla's particular investigations have dealt mainly with X-rays and their absorption and secondary emission by solid substances. He was Nobel laureate in physics in 1917, whilst also in that year he was allotted the Royal Society's Hughes medal.

Prof. Townsend, born in Galway, was educated at Trinity College, Dublin, and at Cambridge. He is a chevalier of the Legion of Honour. In I9I4 he received the Hughes medal of the Royal Society for his researches on electric induction in gases.

Dr. Dale is a Londoner. He was educated at Tollington Park School, London, and the Leys School, Cambridge, graduating afterwards at Trinity College. Last year he was elected one of the secretaries of the Royal Society.

Lord Montagu of Beaulieu was educated at Eton and New College, Oxford. Automobilism and aviation are among his interests. $\mathrm{He}$ is a verderer of the New Forest.

M. FABRY, professor of physics at the Sorbonne, Paris, was born at Marseilles. In 1918, jointly with Dr. A. Perot, the Royal Society allotted them its Rumford medal in respect of their contributions to optics, particularly for the introduction of a new method of measuring wave-lengths by utilising the luminous rings formed by interference between two reflecting plates. Recently Prof. Fabry lecturęd before the Physical Society of London on the absorption of radiation by the upper atmosphere. 